Altun, A. / Sosyal Bilimler Araştırmaları Dergisi. I, (2012): 230-244

\title{
Kanada'daki Sosyal Bilgiler Programlarında Medya Okuryazarlığı Eğitimi
}

\section{Adnan Altun ${ }^{1}$}

\begin{abstract}
Özet
1060'lı y1llarda "Ekran Eğitimi” hareketiyle başlayan Kanada'daki medya okuryazarlığı eğitimi, 2000’li yıllara gelindiğinde Dil Bilimleri, Sosyal Bilgiler, Sağlık Eğitimi ve Bilgi İletişim Teknolojileri derslerinin temel bir parçası olmuştur. Bu araştırmanın amacı hem sosyal bilgiler eğitimi hem de medya okuryazarlığı eğitiminde öncü ülkelerden biri olan Kanada'da Sosyal Bilgiler derslerinde yaygın olarak öğretilen medya okuryazarlığı konularının neler olduğunu ve bu konuların Türkiye'deki Sosyal Bilgiler programıyla nasıl ilişkilendirilebileceğini belirlemektir. Bu amaçla Kanada'daki sosyal bilgiler programları incelenmiş ve medya okuryazarlığı kazanımları içerik analizi yoluyla çözümlenmiştir. Sosyal bilgiler programlarında yer alan medya okuryazarlığı ile ilgili kazanımlar belirli kategorilere ayrılmış ve sonuçta altı tema ortaya çıkarılmıştır. Bunlar; "medya bilgisinin doğruluğu", "medya ve teknoloji”, "güncellik ve küresel sorunlar", "bilinçli tüketici ve medya", "medya ve kültür” ve "medyanın önemi, rol ve sorumlulukları" temalarıdır. Medya okuryazarlığını Türkiye'de uygulanmakta olan 4, 5, 6 ve 7. sınıf Sosyal Bilgiler programlarıyla "Aradisiplin" olarak ilişkilendirmek için Sosyal Bilgiler programı söz konusu temalar doğrultusunda incelenmiştir. İçerik analizi sonucunda önerilen kazanımlardan hareketle ülkemizdeki Sosyal Bilgiler programlarıyla medya okuryazarlığını ilişkilendirmek için bir "Aradisiplin modeli" önerilmiştir.
\end{abstract}

Anahtar kelimeler: Sosyal bilgiler, Medya okuryazarlığı eğitimi, Kanada.

\section{The Media Literacy Education in the Social Studies Curricula in Canada}

\begin{abstract}
In Canada in the late 1960's the first wave of media education began under the banner of "screen education". By 2000 there was new growth in elementary and secondary school media education as media education became a mandated part of the English Language Arts, Social Studies, Health Education and ICT curricula across Canada. This research aims at determining the prevalent media literacy topics at social studies courses in Canada, and how these topics can be integrated into the social studies curricula in Turkey. In the research, the curricula of social studies in Canada were

\footnotetext{
${ }^{1}$ Yrd.Doç.Dr. Abant İzzet Baysal Üniversitesi, Eğitim Fakültesi, İlköğretim Bölümü,
} Sosyal Bilgiler Eğitimi Anabilim Dalı, e-mail: aaltun@ibu.edu.tr
\end{abstract}


examined and the standards for media literacy were analyzed through content analysis. Consequently, the prevalent media literacy topics taught in the courses of social studies were presented under six themes. These are "The Accuracy of Media Information", "Media and Technology", "Actuality and Global Issues", "Media and Conscious Consumer", "Media and Culture" and "The Importance, Role and Responsibilities of Media". The social studies curricula were examined in accordance with the themes stated above in order to integrate media literacy into social studies curricula of 4th, 5th, 6th and 7th grades implemented in Turkey as a sub-discipline. Based on the standards proposed as a result of content analysis, a sub-discipline model was recommended with a view to integrating media literacy into social studies curricula implemented in our country.

Key words: Social Studies, Media Literacy Education, Canada.

\section{GİRIŞ}

Kanada, dünyada medya okuryazarlığı eğitiminde lider ülkelerden biri olarak kabul edilmektedir. "Filin yanındaki fareye" benzeyen Kanadalıların Birleşik Devletlerden ithal edilen yayılmacı medya kültürü karşısında daha analitik ve yansıtıcı bir yaklaşım almak istemeleri doğaldır. Fakat buna karşın Kanada okullarında medya eğitiminin uygulanması yeni bir olgudur.

Kanada okullarındaki medya eğitiminin kökeni 1960'ların sonlarında verilen ilköğretim ikinci kademe "ekran eğitimi" derslerine dayandırılabilir. Büyük bir heyecanla bu dersler 1970'lerin sonlarındaki eğitim reformuyla birlikte önemini kaybetmiştir. Fakat küçük medya eğitimci gruplarının sebatı sayesinde medya eğitimi 1980 ve 90'larda giderek ivme kazanmıştır. 1990'larda Kanada eğitiminde medya eğitiminin de çok büyük bir öneme sahip olduğu etkileyici bir program reformu görülmüştür. $\mathrm{Bu}$ gelişmeler neticesinde Kanada'nın medya okuryazarlığına bakışı şu tanım ile ortaya konulmuştur: "Medya okuryazarlı̆̆ının en büyük amacı basit bir şekilde daha iyi bir farkındalık ve anlayış değil, eleştirel bir özerkliktir" (MOE, 1989: 7; akt. Shibata, 2002: 94). Medya okuryazarlığının "korumacı" bir yaklaşımdan "yetkilendirici" bir yaklaşıma doğru gelişim gösterdiği düşünülecek olursa Kanada'nın "eleştirel özerklik" anlayışının medya okuryazarlığı alanındaki günümüzdeki hâkim yaklaşım (yetkilendirici yaklaşım) ile tutarlı olduğu söylenebilir. 
Duncan, Pungente ve Andersen (2002) Kanada'daki medya eğitimi girişiminin temel nedenlerini şöyle açıklamışlardır: (1) yayılmacı Amerikan popüler kültürüne karşı eleştirel ilgilerimiz ve (2) tüm ülkeyi kapsayan eğitim sistemimizin yeni eğitim paradigmaları için gerekli şartları teşvik etmesi.

Kanada'nın 10 eyaleti ve 3 bölgesinin her birinin kendi eğitim sistemi olmakla birlikte, temel konu alanlarında program çerçevesi geliştirme konusunda işbirliği ülkenin her yerinde resmi statünün kabul edildiği bir medya eğitimi ile sonuçlanmıştır. Okuryazar olmak için çocukların ve gençlerin bilgiyi birçok farklı biçimde okuyabilmeleri, anlayabilmeleri ve eleştirel düşünme becerilerini kullanmaları gerektiği eğitim camiasında bugünlerde yaygın olarak kabul edilmektedir. Bu düşünce WNCP (the Western and Northern Canadian Protocol for Collaboration in Education) ve APEF (the Atlantic Provinces Education Foundation) tarafindan geliştirilen yeni İngilizce Dil Sanatları program çerçevesinde ve Ontario ile Quebec'te geliştirilmekte olan bölgesel öğretim programlarında genel olarak yansıtılmıştır. Sosyal Bilgiler, Sağlık, Vatandaşlık ve Kariyer ve Kişisel Planlama programlarına medya ile ilgili çıktıların ve hedeflerin dâhil edilmesi sayesinde medya eğitiminin programlar arası potansiyeli de fark edilmiştir (MNet, 2009).

Kanada eğitiminin eyaletler arasında farklıklar göstermesinin bir sonucu olarak tüm sınıf seviyelerinde medya eğitimi becerilerinin uygulanması da okuldan okula ve yöreden yöreye değişmektedir. Bazı okul yönetimleri medya eğitimini bir öncelik olarak görmekte ve hizmetiçi eğitim ve medya danışması atama yoluyla destek vermektedir. Bazı okul idareleri de uygulamayı öğretmenin inisiyatifine bırakmaktadır. Tüm bu farklılıklara rağmen sınıflarda dört temel medya eğitimi yaklaşımı kullanılmaktadır (Duncan, Pungente ve Andersen, 2002):

1. Araç Temelli Yaklaşım: Burada belirli bir aracın özelliklerine, güçlü yönlerine ve zayıf yönlerine odaklanılmaktadır. Söz konusu aracın bölümlerinin adlandırılması ile başlayabilir ki burada bir gazetenin veya bir gazete sayfasının tüm bölümlerinin tanımlanması ve sinıflandırılması yapılmaktadır.

2. Konu Temelli Yaklaşım: Konu temelli bir yaklaşım farklı medya araçlarını gerektirir. Cinsiyetin temsili gibi bir konu farklı medya araçlarında nasıl anlatıldığı göre tanımlanabilir ve değerlendirilebilir.

3. Bă̆ımsız Yaklaşım: Birçok öğretmen için bir medya çalışmaları ünitesi İngilizce dersinin içindeki bağımsız bir ünitedir. Bu onların bir davranış 
yada konu seçecekleri ve sadece iki hafta kadar bunu çalışacakları anlamına gelmektedir.

4. İlişkilendirilmiş̧ Üniteler: Medya çalışmalarını diğer sınıf etkilikleriyle ilişkilendirmek çok daha otantik çalışmalar yapmak, yazı ve konuşma gibi daha eski iletişim biçimlerine göre daha yeni olan televizyon ve İnternet gibi medya araçları ile de bağ kurmak için yararlı olabilir.

Medya eğitimini güçlü bir unsur olarak içeren WNCP İngilizce Dil Bilimleri çerçevesi 1997 'de tamamlanmış olmasına rağmen Sosyal bilgiler alanında henüz ortak bir çerçeve oluşturulmamıştır. Sosyal Bilgiler derslerinde medya okuryazarlığı eğitimi ile ilgili en detaylı vurgulama British Columbia Eğitim Bakanlığı (2006: 24) tarafından yapılmıştır:

"Halk sorunlara ve olaylara ilişkin aldığı bilginin çoğunu gazete, dergi, radyo, televizyon ve Internetteki medya mesajlarindan edinmektedir. Medya mesajlarının analizi Sosyal Bilgilerin değerli bir bileşenidir ve ögrencilerin etkilendikleri sorunlara ilişkin eleştirel ve bağımsı düşünmelerini sağlar. Aşağıdaki medya ĕgitimi kavramlar öğretmenlerin ve öğrencilerin çeşitli medya mesajlarını değerlendirme yollarının örnekleridir:

Amaç: Insanlar medya mesajlarını politik, ticari, eğitimsel, sanatsal ve farklı amaçlarla bilgi edinmek, eğlenmek ve ikna etmek için kullanırlar.

Değerler: Medya mesajları açık şekilde veya üstü örtülü değerleri iletir.

Temsil: Medya mesajları kurgulanmıştır: sadece gerçeğin yeniden sunumu yada hayali dünyalardır.

Kodlar, Ĕğilimler ve Özellikler: Her araç mesajları iletilme ve anlaşılma biçimlerini etkileyen bir takım kodlara, eğilimlere ve özelliklere sahiptir.

Yapım: Medyayı anlayan insanlar çok daha anlamlı medya mesajları yapabilir. Yorum: İzleyicilerin medya mesajlartyla ilgili yorumlarl ve bunlara duygusal tepkileri onların bilgi, deneyim ve değerlerinden hâsıl olur.

Medyanın İleyiciler Üzerindeki Etkisi: Medya mesajlart insanların tutumlarını, davranışlarını ve değerlerini etkileyebilir.

Izleyicilerin Medya Üzerindeki Etkisi: Insanlar medya kurumlart ile onların ürettikleri ve ilettikleri medya mesajların etkileyebilir.

Kontrol: Bir toplumun egemen kurumların kontrol eden insanlar medya mesajlarının yapısı ve dağıtılması ve içerdikleri değerler üzerinde oransız, gereğinden fazla etkiye sahip olabilirler.

Kapsam: Medya teknolojileri toplumların politik, ekonomik, toplumsal ve entelektüel boyutların etkilemekte ve bu boyutlardan etkilenmektedir." 
British Columbia Eğitim Bakanlığı sosyal bilgiler programlarında medya okuryazarlığının önemini altı kalın çizgilerle çizilmekle birlikte, diğer eyaletler ve bölgelerde de öğrenme çıktıları ve hedefleri ilave edilerek medya okuryazarlığına sosyal bilgiler programlarında yer verilmiştir.

\section{Araştırmanın Amacı}

$\mathrm{Bu}$ çalışmada söz konusu öğrenme çıktıları ve hedefleri incelenerek medya okuryazarlığının sosyal bilgiler programlarıyla nasıl ilişkilendirileceğini ortaya koymak amaçlanmıştır.

\section{Araştırmanın Yöntemi}

$\mathrm{Bu}$ çalışmada araştırma yöntemi olarak içerik analizine başvurulmuştur. İçerik analizi, belirli bir mesajın kapsadığı, taşıdığı enformasyonun işlenmesini temel almaktadır. Yöntemin ilk adımı "betimsel işleme"dir. Burada, bireyin aldığı uyaranların veya mesaj öğelerinin özelliklerini ve güçlerini objektif bir şekilde ortaya koyarak sübjektif ve kaba betimlemeleri aşmak söz konusudur.

$\mathrm{Bu}$ açıdan içerik analizi, iletişimlerim kodlanması sorunuyla, mesajın bir takım kategorilere bölmek, belirli kodlama yada kayıt birimleri saptamakla işe başlayacaktır (Bilgin, 2000: 10). Kategorileştirme, tanımı gereği, bir bütünü oluşturan öğeleri belirli kriterlere göre birbirinden farklılaştırarak gruplandırmak demektir. Kategorilendirme, mesaj öğelerinin tek tek ayırt edilmesini ve ardından belirli gruplara dağıtılmasını gerektirmektedir.

İçerik analizinde kategorilendirmede "kapalı yaklaşım" ve "açık yaklaşım" olmak üzere iki farklı yaklaşım vardır. Kapalı yaklaşımda araştırma konusuyla ilgili önceden var olan kategoriler kullanılırken, açık yaklaşımda kategoriler içerik analizi sonucunda oluşturulur. Kısaca kapalı yaklaşımda içerik analizi tümden gelimsel bir yapıya sahipken, açık yaklaşımda tümevarımsal bir nitelik söz konusudur.

$\mathrm{Bu}$ çalışmada açık yaklaşıma başvurulmuştur. Sosyal bilgiler derslerinde medya okuryazarlı̆̆ının nasıl öğretileceğine, daha da önemlisi hangi konuların öğretileceğine ilişkin literatürde kabul görmüş herhangi bir model bulunmamaktadır. $\mathrm{Bu}$ nedenle söz konusu ülkedeki sosyal bilgiler programlarında yer alan medya okuryazarlığı ile ilgili kazanımlar belirli kategorilere ayrılmıştır. Bu kategorilendirme işlemi yapılırken şu hususlara dikkat edilmiştir:

- Kategoriler homojen olmalıdır; farklı öğeler aynı kategoride yer almamalidir. 
- Kategoriler bütünsellik taşımalı, iletişim veya mesajın tümünü kapsamalıdır.

- Kategoriler ayrıt edici olmalı, bir öğe, farklı kategorilerde yer almamalıdır.

- Kategoriler objektif olmalı, farklı kodlayıcılar aynı öğeleri, aynı kategorilere sokmalıdır (ya da aynı kodlayıcı aynı öğeleri, farklı zamanlarda aynı kategorilere sokmalıdır).

- Kategoriler, amaca uygun ve anlamlı olmalı, araştırma hedeflerine göre uyarlanmalıdır (Bardin, 1977: akt. Bilgin, 2000: 11).

İçerik analizi tekniklerinin güvenirliği büyük ölçüde kodlama işlemine bağlıdır (Ghiglione, 1978: akt. Bilgin, 2000: 13-14): Bu ise, kodlayıcıların ve kodlama kategorilerinin güvenirliğiyle ilgilidir. Araştırmada yapılan içerik analizinde kodlayıcının güvenirliği için aynı kodlayıcının aynı metni farklı zamanlarda aynı şekilde kodlaması tercih edilmiştir. Ülkemizde medya okuryazarlığı yeni yeni tanınmaya başlandığı bir dönemde genel olarak medya okuryazarlığı alanında, özelde de sosyal bilgiler eğitimi çerçevesinde medya okuryazarlığ konusunda yetişmiş uzman olmadığ 1 için bu yola başvurulmuştur. Araştırmacı öncelikle sosyal bilgiler alanının temelini oluşturan disiplinleri (tarih, coğrafya, sosyoloji vb. gibi) esas alarak bir kodlama yapmış, ardından sosyal bilgiler programındaki öğrenme alanlarına göre bir kodlama gerçekleştirmiş̧ir. Ancak daha sonra medya okuryazarlığı alanına yoğunlaştığında kodlama işlemini medya okuryazarlığını temel alarak gerçekleştirmiştir. Yapılan kategorilendirme üç defa tekrarlanarak yapılan içerik analizinin güvenirliği sağlanmaya çalışılmıştır.

İçerik analizinin geçerliliği ise, amaçlar ve araçlar arasındaki uygunlukla ilgilidir. İçerik analizi tekniklerinin olayları/mesajları bozmadan amaca ulaşmayı sağlaması gereklidir. Tıpkı diğer yöntemler için olduğu gibi, içerik analizi için de farklı geçerlik türlerinden söz edilebilir: İçerik geçerliliği, tahmin geçerliliği, karşılaştırma geçerliliği, yorum geçerliliği (Bilgin, 2000: 14). İçerik geçerliliğine yönelik, araştırmada yapılan kodlamalar farklı ülke (ABD, Avustralya gibi) programlarıyla karşılaştırılmıştır. Ancak farklı çalışmalarda değerlendirileceği için diğer ülkelere ait verilere burada yer verilmemiştir.

\section{İçerik Analizinin Kapsamı}

Araştırmanın amacını gerçekleştirmek için medya okuryazarlığı konusunda uzmanlaşmış ülkelerden biri olarak kabul edilen Kanada inceleme 
konusu yapılmıştır. Çeşitli eyaletlerden oluşan Kanada eğitim sitemi incelenmiş ve medya okuryazarlığının ilişkilendirildiği sosyal bilgiler öğretim programları eyaletlere göre tespit edilmiştir. Kanada'da 10 eyalet ve üç bölge bulunmaktadır. $\mathrm{Bu}$ eyalet ve bölgelerde medya okuryazarlığı mevcut öğretim programlarıla ilişkilendirilmiştir. Medya okuryazarlığı bu eyaletlerin dil programlarının \%100'üyle, sağlık eğitimi programlarının \%85'iyle, sosyal bilgiler programlarının \%54'üyle ve son olarak da bilgi ve iletişim teknolojileri programlarının \%38'iyle ilişkilendirilmiştir (bkz. Tablo 1). Kanada'da medya okuryazarlığı 7 eyaletin Sosyal Bilgiler programları ile ilişkilendirilmiştir. Bu eyaletlerden dördü (New Brunswick, Nova Scotia, Prince Edward Island ve Newfoundland and Labrador) aynı programa sahiptir. Bu nedenle eyaletlerden sadece biri (New Brunswick) ele alınmıştır. Bunun dışında farklı program yapılarına sahip iki eyalet (Alberta ve British Columbia) daha incelenmiştir. Ayrıca Ontario eyaleti de sadece lise düzeyine hitap ettiği için kapsam dışı bırakılmıştır.

Tablo 1: Kanada'da medya okuryazarlığının öğretim programlarıyla ilişkilendirilme düzeyi ${ }^{2}$

\begin{tabular}{|l|c|c|c|c|}
\hline & $\begin{array}{l}\text { Dil } \\
\text { Bilimle } \\
\text { ri }\end{array}$ & $\begin{array}{l}\text { Sağlik } \\
\text { Eğitim } \\
\text { i }\end{array}$ & $\begin{array}{l}\text { Sosyal } \\
\text { Bilgile } \\
\text { r }\end{array}$ & $\begin{array}{l}\text { Bilgi ve } \\
\text { İletişim } \\
\text { Teknolojileri }\end{array}$ \\
\hline British Columbia & $\mathrm{x}$ & $\mathrm{x}$ & $\mathrm{x}$ & \\
\hline Alberta & $\mathrm{x}$ & $\mathrm{x}$ & $\mathrm{x}$ & $\mathrm{x}$ \\
\hline Saskatchewan & $\mathrm{x}$ & $\mathrm{x}$ & & $\mathrm{x}$ \\
\hline Manitoba & $\mathrm{x}$ & $\mathrm{x}$ & $\mathrm{x}$ & \\
\hline Ontario & $\mathrm{x}$ & & & \\
\hline Quebec & $\mathrm{x}$ & $\mathrm{x}$ & $\mathrm{x}$ & \\
\hline New Brunswick & $\mathrm{x}$ & $\mathrm{x}$ & $\mathrm{x}$ & $\mathrm{x}$ \\
\hline Nova Scotia & $\mathrm{x}$ & $\mathrm{x}$ & $\mathrm{x}$ & $\mathrm{x}$ \\
\hline Prince Edward Island & $\mathrm{x}$ & & $\mathrm{x}$ & \\
\hline $\begin{array}{l}\text { Newfoundland and } \\
\text { Labrador }\end{array}$ & $\mathrm{x}$ & $\mathrm{x}$ & & \\
\hline Nunavut & & & \\
\hline
\end{tabular}

${ }^{2}$ Kanada sosyal bilgiler programlarındaki medya okuryazarlığı kazanımlarına internet yoluyla (http://www.media-awareness.ca/) ulaşılmıştır. Bu kazanımlar Türkçeye tercüme edilmiş ve içerik analizi yöntemi kullanılarak incelenmiştir. 
Altun, A. / Sosyal Bilimler Araştırmaları Dergisi. I, (2012): 230-244

\begin{tabular}{|l|c|c|c|c|}
\hline Northwest Territories & $\mathrm{x}$ & $\mathrm{x}$ & & \\
\hline Yukon & $\mathrm{x}$ & $\mathrm{x}$ & & \\
\hline TOPLAM \% & 100 & 85 & 54 & 38 \\
\hline
\end{tabular}

\section{BULGULAR}

Kanada sosyal bilgiler programlarında yer alan medya okuryazarlığ kazanımları içerik analizi yöntemiyle incelenmiş ve bu incelemenin sonuçları "Tablo-2"de verilmiştir. İnceleme sonucunda altı adet tema ortaya çıkmıştır. Bu temalarda yer alan kazanımların hangi eyalete olduğu A (Alberta), BC (British Columbia) ve NB (New Brunswick ve diğerleri) harfleri sembolize edilmiştir. Ayrıca bu kazanımların hangi sınıf seviyesinde yer aldığ da A (Okul öncesi), 13 (1, 2 ve 3. siniflar), 4-6 (4, 5, ve 6. siniflar), 7-9 (7, 8 ve 9. siniflar) ve 10-12 $(10,11$ ve 12. sınıflar) ile gösterilmiştir. Tüm bu kazanımların toplamı ve yüzdesi verilerek temaların, bütün içindeki ağırlığı da gösterilmeye çalışılmıştır.

Tablo 2: Kanada sosyal bilgiler programlarındaki medya okuryazarlığı kazanımlarının içerik analizi sonuçları

\begin{tabular}{|c|c|c|c|c|c|c|c|c|c|}
\hline & & & & & & & & & \\
\hline & $\begin{array}{l}\text { Standart } \\
\text { Konusu }\end{array}$ & $\begin{array}{c}\text { Eyaletle } \\
\mathbf{r}\end{array}$ & $\mathbf{A}$ & $1-3$ & 4-6 & $7-9$ & $\begin{array}{l}10- \\
12\end{array}$ & $T$ & $\%$ \\
\hline 1 & $\begin{array}{l}\text { Medya } \\
\text { Bilgisinin } \\
\text { Doğruluğu }\end{array}$ & $\begin{array}{c}\mathrm{A}, \mathrm{BC} \\
\mathrm{NB}^{3}\end{array}$ & 1 & 5 & 7 & 13 & 1 & 34 & 34.7 \\
\hline 4 & $\begin{array}{l}\text { Medya ve } \\
\text { Teknoloji }\end{array}$ & $\begin{array}{c}\mathrm{A}, \mathrm{BC} \\
\mathrm{NB}\end{array}$ & 2 & 4 & 4 & 2 & 4 & 16 & 16.3 \\
\hline 2 & $\begin{array}{l}\text { Güncellik ve } \\
\text { Küresel } \\
\text { Sorunlar }\end{array}$ & $\begin{array}{c}\mathrm{A}, \mathrm{BC} \\
\mathrm{NB}\end{array}$ & & 1 & 4 & 3 & 5 & 13 & 13.3 \\
\hline 3 & $\begin{array}{l}\text { Bilinçli } \\
\text { Tüketici ve } \\
\text { Medya }\end{array}$ & NB & & 3 & 4 & 3 & 3 & 13 & 13.3 \\
\hline 5 & $\begin{array}{l}\text { Medya ve } \\
\text { Kültür }\end{array}$ & A, NB & & 1 & 2 & 3 & 5 & 11 & 11.2 \\
\hline \begin{tabular}{l|l}
6 \\
\end{tabular} & Medyanın & $\mathrm{A}, \mathrm{NB}$ & & 2 & 2 & 3 & 4 & 11 & 11.2 \\
\hline
\end{tabular}

3 "New Brunswick eyaletinin sosyal bilgiler programı Nova Scotia, Prince Edward Island ve Newfoundland and Labrador eyaletleri ile aynı program olduğu için ayrıca ifade edilmemiştir. 
Altun, A. / Sosyal Bilimler Araştırmaları Dergisi. I, (2012): 230-244

\begin{tabular}{|l|l|l|l|l|l|l|l|l|l|}
\hline & $\begin{array}{l}\text { Önemi, Rol ve } \\
\text { Sorumluluklar1 }\end{array}$ & & & & & & & & \\
\hline
\end{tabular}

$\mathrm{Bu}$ tablo incelendiğinde "Medya Bilgisinin Doğruluğu” temasının ön plana çıktığı görülmektedir. Bu tema incelenen üç eyaletin programlarında da yer almış olması, tüm sınıf seviyelerinde bulunması ve \%35'lik bir orana, tüm kazanımların 1/3'üne sahip olması gibi sebeplerle sosyal bilgiler programları için vazgeçilmez bir medya okuryazarlığı konusu olarak görülebilir. Kazanımların özellikle ilköğretim düzeyinde yoğunlaşması dikkat çekicidir. Daha ayrıntılı olarak analiz edildiğinde alt tema olarak şu konular ifade edilebilir:

- Olası kaynakları tespit etmek

- Çeşitli sembolik temsilleri tanımak

- Yazılı ve yazılı olmayan kaynaklardan bilgiyi elde etmek

- Araştırma tekniklerini etkin olarak kullanmak

- Medya araçlarındaki çeşitli bakış açılarını eleştirel olarak anlayarak ve takdir ederek dinlemek

- (Tarihsel kanıtları da içeren) Bilgiyi analiz etmek;

- Amacı fark ederek

○ Bağlamı görerek

- Objektif olarak

○ Olguyu görüşten ayırt ederek

- Birinci ve ikinci elden kaynakları tanıyarak

○ Önyargıyı ve kalıp yargıуı fark ederek

○ (Alternatif) Bakış açılarını fark ederek ve bunlara saygı duyarak

○ İnanırlı̆̆ını ve güvenilirliğini takdir ederek

- Elde ettiği bilgiyi kullanmak

- Bilgi ve teknolojinin sorumlu ve etik kullanımını yaparak göstermek

“Medya ve Teknoloji” temas1 \%16'llk bir orana sahiptir ve incelenen üç programının üçünde de yer almaktadır. Ayrıca okul öncesinden liseye tüm sınıf seviyelerinde neredeyse eşit oranda kazanım yer almaktadır. Medya ve Teknoloji teması daha ayrıntılı olarak analiz edildiğinde alt tema olarak şu konular ifade edilebilir: 
- Yaşamlarında kullandıkları teknolojilere örnekler vermek

- Teknolojileri kullanma şekillerini tanımlamak

- Teknolojinin bireyleri ve teknolojileri nasıl etkilediğini tanımlamak

- Kanada'da iletişim teknolojilerinin önemini analiz etmek

- Yaşam tarzları ve çevreleri üzerinde teknolojinin etkilerini değerlendirmek

- Bilgisayar teknolojisinin toplum üzerindeki etkilerini tanımlamak

- Politik, kültürel ve ekonomik faaliyetin düzenlenmesinde iletişim sistemlerinin oynadığı ve oynamaya devam ettiği tarihsel ve çağdaş rolleri analiz etmek

Çalışmada ön plana çıkan temalardan bir diğeri de “Güncellik ve Küresel Sorunlar”dır. Tüm kazanımlar içinde \%13'lük bir orana sahiptir ve incelenen üç öğretim programında da yer almaktadır. Ayrıca okul öncesi dışında tüm sınıf seviyelerinde yer aldığ 1 görülmektedir. İlköğretim seviyesinde de önemli oranlarda bulunmakla birlikte daha çok lise düzeyinde ele alındığ 1 söylenebilir. Güncellik ve Küresel Sorunlar teması daha ayrıntılı olarak analiz edildiğinde alt tema olarak şu konular ifade edilebilir:

- Küresel sorunların çözümlerini göstermek için birkaç örneği çalışmak

○ Tüketici farkındalığı

○ Eğitim

○ Uygun teknoloji

○ Gönüllülük

○ Toplumsal eylem

- Değişen teknolojilerin küresel toplum üzerindeki etkilerini analiz etmek

- Değişen teknolojilerin küresel ekonomi üzerindeki etkilerini değerlendirmek ve tanımlamak

- Evrensel insan hakları ve adalet ilkeleri ile ilgili durumları ve politika beyanlarını analiz etmek

“Bilinçli Tüketici ve Medya” teması da \%13'lük oranıla dikkat çekmektedir. İncelenen üç farklı programın ikisinde ilgili kazanımlar görülebilmektedir. Okul öncesi hariç tüm sınıf düzeylerinde yer aldığ 1 ve eşit bir dağılım gösterdiği görülmektedir. Ancak bu temaya sadece New Brunswick 
eyaletine ait programda yer verilmiştir. $\mathrm{Bu}$ eyalete ait programın aynısının üç farklı eyalette de kullanıldığını gözden kaçırmamak gerekmektedir. Sonuç olarak bu temanın da sosyal bilgiler programlarında önem taşıdığı söylenebilir. Tema daha ayrıntılı bir şekilde analiz edildiğinde şu konular ön plana çıkmaktadır:

- Tüketici kararlarının ekonomiyi nasıl etkilediğini açıklamak

- Tüketici-yönelimli toplumun gelecekteki sonuçlarını değerlendirmek

- Reklâmcılar ve propagandacıların çıkarlarını desteklemek için çeşitli medya biçimlerini nasıl kullanabildiklerini değerlendirmek

- Tüketici seçimlerine dikkat etmek

- Etkileyen etmenleri taniyarak

○ İhtiyaç ve istekleri ayırt ederek

- Akranların etkisini fark ederek

- Reklâmları analiz ederek

- Propagandayı fark ederek

“Medya ve Kültürr” temas1 \%11'lik bir orana sahiptir. Okul öncesi dışında tüm sınıf seviyelerinde olmakla birlikte kazanımlar daha çok lise dizeyinde yer almaktadır. Medya ve Kültür teması daha ayrıntılı olarak analiz edildiğinde alt tema olarak şu konular ifade edilebilir:

- Kültürün nasıl korunduğuna ve yayıldığına örnekler vermek

- Dil, edebiyat, sanatlar, mimarlık, diğer eserler, gelenekler, inançlar, değerler ve davranışlar kültürün gelişmesi ve yayılmasına nasıl katkıda bulunduğunu açıklamak

- Kültürün nasıl korunduğunu ve yayıldığını karşılaştırmak ve analiz etmek

- Kültürler üzerinde ekonomik, politik ve teknolojik değişimlerin etkisi hakkında bir anlayış göster

- Medyanın diğer kültürlerle olan etkileşimimize avantajlarını ve dezavantajlarını görmek

“Medyanin Önemi, Rol ve Sorumluluklart” temas1 da \%11'lik bir orana sahiptir. İncelenen üç farklı programın ikisinde ilgili kazanımlar görülebilmektedir. Okul öncesi hariç tüm sınıf düzeylerinde yer aldığı ve eşit bir dağılım gösterdiği görülmektedir. Tema daha ayrıntılı bir şekilde analiz edildiğinde şu konular ön plana çıkmaktadır: 
- Televizyon ve diğer medya araçlarının imajları yaratmak, istekleri iletmek, politikaları ve fikirleri yaymak için nasıl kullanıldığını değerlendirmek

- Medya bağlamında;

- Grupların ve kurumların insanları ve toplumu nasıl etkilediğine örnekler vermek

- Grupların ve kurumların insanları ve toplumu nasıl etkilediğini tanımlamak

- İnsanların grupları ve kurumları nasıl etkilediğini tanımlamak

- Hem tarihsel hem de çağdaş durumlarda bireylerin grupları ve kurumları nasıl etkilediğini analiz etmek

$\mathrm{Bu}$ altı tema Kanada'da sosyal bilgiler derslerinde yoğun olarak öğretilen medya okuryazarlığını konularını ortaya koymaktadır. Analiz sonucunda ortaya çıkan ayrıntılar medya okuryazarlığını sosyal bilgiler programıyla ilişkilendirme konusunda önemli fikirler vermektedir. Örneğin ülkemiz bağlamında medya okuryazarlığını sosyal bilgiler programıyla ilişkilendirirken, bu ayrıntılar medya okuryazarlığı becerisinin alt başlıkları olarak ele alınabileceği gibi medya okuryazarlı̆̆ 1 ara disiplininin kazanımları olarak da kullanılabilir.

\section{TARTIŞMA ve SONUÇ}

ABD'nin yayılmacı medya kültürü karşısında medya okuryazarlığını koruyucu bir kalkan olarak gören Kanada, bu konuya ayrı bir önem vermektedir. Ancak şu bir gerçek ki ABD'nin ya da başka bir ülkenin medya kültürüne maruz kalmak sadece o ülkenin komşuları için geçerli olan bir durum değildir. Çünkü gelişen iletişim teknolojileri ile küresel bir köye indirgenen dünyada herkes her an her şeyden haberdar olabilmekte, medya kültürü dünyanın en ücra yerlerine sızabilmektedir. Kısacası Kanada'nın, ABD’nin yayılmacı medya kültürüne yönelik hassasiyetinin ve medya okuryazarlığına önem vermesinin gerekçeleri Türkiye için de, dünya üzerinde ki başka ülkeler için de geçerlidir. Kaldı ki medya okuryazarlığını yayılmacı medya kültürü karşısında bir koruyucu nitelendirmesine indirgemek de çok doğru bir yaklaşım olmayacaktır.

Medya okuryazarlığı bireylere yetki vermeyi amaçlayan bir eğitimi öngörmektedir. Ayrıca medya kullanımında bireyin memnuniyetini de 
önemsemektedir. Kısacası medya okuryazarlığ 1 koruyucu olmakla birlikte yetkilendirici ve eğlendirici bir eğitimi öngörmektedir.

Medya okuryazarlığı çağımız vatandaşının haklarını etkili bir şekilde kullanabilmesi için de vazgeçilmez bir eğitim unsurudur. Gerçekten demokratik bir toplumda birey, medyanın propaganda, manipülasyon, dezenformasyon, sansasyon vb. güçlerini fark etmeden vatandaşlık haklarını, örneğin bilgi edinme hakkını nasıl etkin bir şekilde kullanabilir ki? Bu soruya evet cevabını vermek imkânsız görünüyor. Böylece medya okuryazarlığı vatandaşlık eğitiminde de etkin bir rol üstelenebilmektedir.

Yaşadığımız tüketim çağı bireylerin bilinçli tüketiciler olmasını da gerektirmektedir. Medya okuryazarlığı eğitimi ile bireyler istek ve ihtiyaçlarını ayırt ederek, reklamları çözümleyerek, propagandayı ve ikna etme tekniklerinin farkına vararak bilinçli bir tüketici olma yolunda kendini geliştirebilecektir.

Bundan dolayı medya okuryazarlığı Türk eğitim sistemi içinde yerini alması gereken önemli başlıklardan biridir. Öyleyse medya okuryazarlığı eğitim sistemimize nasıl dâhil edilebilir? RTÜK ve MEB yapmış oldukları "Seçmeli Medya Okuryazarlığı Dersi” ile bu soruya bir cevap vermişlerdir. Ancak ne kadar etkili bir cevap olduğu tartış1labilir. İlköğretimin ilk kademesinde ve ortaöğretimde yer almayan, ilköğretimin ikinci kademesinde ve seçmeli olarak verilen bir dersin etkililiği oldukça tartışılacak bir mevzudur. Özellikle de medya okuryazarlığının doğası dikkate alındığında.

Medya okuryazarlığı uzmanları medya okuryazarlığını bir kategori değil, devamlı ve aralıksız bir bütün (continuum) olarak (Potter, 1998: 4; Thoman, 2003), bir ders değil bir beceri ve yetenek olarak (Considine, 1999; Duncan, Pungente ve Andersen: 2002) ve hayat boyu devam eden bir süreç olarak (Masterman, 2001) değerlendirmektedirler. Özellikle Masterman (2001) pek çok çocuğun medyaya olan ilgisi ve sevgisinin okul çağından önce başladığını ve yaşamlarının sonuna kadar devam ettiğini ifade etmiştir. $\mathrm{Bu}$ gerçeğin farkına varılmadan verilen bir medya eğitiminin başarısız olacağını dile getirmekte ve medya eğitiminin okul sonrasında da devam etmesi için hem eğlendirici ve tatmin edici hem de eğitici bir deneyim sağlanılmasının zorunlu olduğunu ileri sürmektedir.

Gelişimi hayat boyu devam eden bir beceri olarak kabul edilirse, medya okuryazarlığının ayrı bir ders olmaktan ziyade diğer derslerle ve bu derslerin programlarıyla ilişkilendirilebilecek disiplinler arası bir konu olduğu düşünülebilir. 
$\mathrm{Bu}$ çalışmada da medya okuryazarlı̆̆ kabul edilmiş ve Kanada örneği üzerinden medya okuryazarlığının Sosyal Bilgiler programıla nasıl ilişkilendirileceği konusuna açılık getirmeye çalışılmıştır.

Yapılan içerik analiz sonucunda Kanada sosyal bilgiler programlarında yoğun olarak öğretilen medya okuryazarlı̆̆1 konuları ortaya konulmaya çalışılmıştır. Bu konular altı farklı tema altında şöyle ifade edilmiştir: "medya bilgisinin doğruluğu, medya ve teknoloji, güncellik ve küresel sorunlar, bilinçli tüketici ve medya, medya ve kültür, medyanın önemi, rol ve sorumlulukları".

Medya okuryazarlı̆̆ı, ülkemiz sosyal bilgiler programlarına bir ara disiplin ya da bir beceri olarak ilişkilendirilebilir.

Çalışmada ortaya çıkan medya okuryazarlığ temaları ülkemizdeki ve pek çok ülkedeki sosyal bilgiler programının üzerine inşa edilen öğrenme alanlarıyla da ilgilidir. Tablo-3'te bu ilişki ortaya konulmaya çalışılmıştır.

Tablo 3: Araştırmada ulaşılan medya okuryazarlığı temalarının sosyal bilgiler öğrenme alanları ilişkilendirilmesi

\begin{tabular}{|c|c|}
\hline Medya Okuryazarlığı Temaları & Sosyal Bilgiler Öğrenme Alanları \\
\hline Medya Bilgisinin Doğruluğu & Zaman, Sürelilik ve Değişim \\
\hline Medya ve Teknoloji & Bilim, Teknoloji ve Toplum \\
\hline Güncellik ve Küresel Sorunlar & Küresel Bağlantılar \\
\hline Bilinçli Tüketici ve Medya & Üretim, Dağıtım ve Tüketim \\
\hline Medya ve Kültür & $\begin{array}{c}\text { Birey ve Toplum / Kültür ve Miras / } \\
\text { İnsanlar, Yerler ve Çevreler }\end{array}$ \\
\hline Medyanın Önemi, Rol ve & Gruplar, Kurumlar ve Sosyal Örgütler / \\
Sorumlulukları & Güç, Yönetim ve Toplum \\
\hline
\end{tabular}

Tablo 3'ten de anlaşılabileceği gibi "Medya Bilgisinin Doğruluğu" teması "Zaman, Süreklilik ve Değişim” öğrenme alanı ile ilişkilendirilebilir. Çünkü ilgili tema tıpkı bu öğrenme alanı gibi diğer tüm öğrenme alanlarıyla ilgilidir. Medyadan elde ettiğimiz bilgiler sadece toplumsal olmuyor, aynı zamanda kültürel, teknolojik, bilimsel, küresel, ekonomik, tarihi, coğrafi, kurumsal ve siyasi de olabiliyor. Bu nedenle tüm bu bilgileri bir medya okuryazarı gibi ele alabilmeliyiz.

"Medya ve Teknoloji” teması "Bilim, Teknoloji ve Toplum" öğrenme alanı ile; "Güncellik ve Küresel Sorunlar" temas1 "Küresel Bağlantılar" öğrenme alanı ile; "Bilinçli Tüketici ve Medya" teması "Üretim, Dağıtım ve 
Tüketim" öğrenme alanı ile; "Medya ve Kültür" teması ise "Birey ve Toplum", "Kültür ve Miras" ve "İnsanlar, Yerler ve Çevreler" öğrenme alanları ile ve "Medyanın Önemi, Rol ve Sorumlulukları" teması da "Gruplar, Kurumlar ve Sosyal Örgütler" ve "Güç, Yönetim ve Toplum” öğrenme alanlarıyla ilişkilendirilebilir.

Sonuç olarak bu çalışmada medya okuryazarlığı eğitimi konusundaki program ilişkilendirme yaklaşımı, Kanada örneği üzerinden ve sosyal bilgiler dersi bağlamında ortaya konulmaya çalışılmıştır. Yapılan araştırmanın özellikle sosyal bilgiler eğitimi bağlamında ülkemizdeki medya okuryazarlığı çalışmalarına katkı sağlaması ümit edilmektedir.

\section{KAYNAKLAR}

Bilgin, N. (2000), İçerik Analizi. İzmir: Ege Üniversitesi Edebiyat Fakültesi Yayınları.

British Columbia Ministry of Education (2006), Social Studies, Kindergarden to Grade 7: Integrated Resource Package. 12.06.2009 tarihinde http://www.bced.gov.bc.ca/irp/ssk7.pdf adresinden elde edilmiştir.

Considine, D. (1999), Case FOR Media Literacy in Today's Schools. http://medialit.org/reading_room/article368.html adresinden 23.05.2008 tarihinde alınmıştır.

Duncan, B., J. Pungente ve N. Andersen (2002), Media Education in Canada. http://www.aml.ca/articles/articles.php?articleID $=272$ adresinden 30.06.2009 tarihinde elde edilmiştir.

Masterman, L. (2001), A Rationale for Media Education. Media Literacy in the Information Age: Information \& Behavior. Ed. Robert Kubey. New Brunswick and London: Transaction Publishers.

MNet (Media Awareness Network) (2009), Media Education in Canada: An Overview. 12.06.2009 tarihinde www.mediaawareness.ca adresinden elde edilmiştir.

Potter, W. J. (1998), Media Literacy. California: Sage Publications.

Shibata, K. (2002), Analysis of "Critical" Approach in Media Literacy: Comparative Studies between Japan and Canada. Keio Communication Review No. 24, 2002

Thoman, E. (2003), Skills and Strategies for Media Education. 28.02.2006 tarihinde www.medialit.org adlı İnternet sayfasından elde edilmiştir. 